\title{
EVALUATION OF TWO SURGICAL TREATMENTS OF PRIMARY VESICOURETERAL REFLUX AMONG CHILDREN: A 15 YEARS EXPERIENCE
}

\author{
Memeti Shaban, ${ }^{1,2}$ Petrovski Mile, ${ }^{1}$ Petrovski Pero, ${ }^{1}$ Simeonov Risto, ${ }^{1}$ \\ Kamilovski Marjan, ${ }^{1}$ Todorovic Lazar, ${ }^{1}$ Ziberi Jetmir, ${ }^{1}$ Ristevski Toni, ${ }^{1}$ \\ Lumani Njomza, ${ }^{1}$ Mihajlova Mila, ${ }^{1}$ Ristovska Gordana ${ }^{2}$ \\ ${ }^{1}$ University Clinic for Pediatric Surgery, Faculty of Medicine - Skopje, \\ "Ss. Cyril and Methodius" University - Skopje, Republic of Macedonia \\ ${ }^{2}$ Institute of public health of Republic of Macedonia, Skopje, Republic of Macedonia
}

Primljen/Received 19. 04. 2016. god.

Abstract: Aim: aim of the study was to evaluate the efficiency of two different surgical treatments of vesicoureteral reflux (VUR) on succesfull rate and patient outcome.

Methods: Retrospective study on children with primary VUR and their surgical treatment from 1999 to 2014 in the University Clinic for Pediatric Surgery in Skopje. A total of 76 children (114 ureters) with VUR ranging from second to fifth grade were treated surgically, 44 patients (67 ureters) with an open surgical technique and 32 patients (47 ureters) with endoscopic treatment "STING" procedure. The following parameters were analyzed: duration of the intervention, duration of the hospitalization, the need for antibiotics and analgesic therapy and the need for blood and blood derivatives transfusion. The result of the surgical treatment was also validated. A good result was considered when reduction of VUR by 2 degrees with the endoscopic method or by 3 degrees in the open surgical technique was noticed.

Results: Using open surgical technique, patients were hospitalized for an average of 9 days (range from 5 to 13 days). All children received double antibiotic therapy. The need for analgesics lasted for 3 to 4 days. $90 \%$ of treated children needed blood and/or blood derivatives transfusion. Success rate with this method was $93.8 \%$. Endoscopic procedure was performed as a one-day surgical procedure. The average duration was 15 minutes. Single, prophylactic dose of antibiotic was ordinated. There was no need for blood and/or blood derivatives transfusion. The overall success of the treatment was about $70 \%$.
Prihvaćen/Accepted 15. 06. 2016. god.

Conclusion: Open surgical procedure is used for more complicated cases, VUR grade IV-V or by previously failed. Endoscopic, "STING" procedure was commonly used for patients with VUR grade greater than 2, after previously failed conservative treatment, febrile urinary infection despite antibiotic prophylaxis and/or emergence of new scarring in the renal parenchyma. $\mathrm{Pa}$ tient assessment and decision for what method will be used must always be done individually for each child.

Key words: children; primary vesicoureteral reflux; surgical treatment, endoscopic treatment.

\section{INTRODUCTION}

Vesicoureteral reflux is one of the most common pathologies seen in pediatric patients. This treatment requires a multidisciplinary approach, starting from an accurate diagnosis based on heteroanamnestic data, pre-clinical, radiological, radio isotopic and laboratory investigations. Selecting the correct treatment, further control and follow-up of the affected child should be individualized $(1,2,3)$.

The term vesicoureteral reflux (VUR) represents a retrograde flow of urine from the bladder to the proximal parties of the urinary tract. The ureter is normally attached to the wall of the bladder in tilted position, passing through detrusor muscle, continuing between the mucosa of the bladder and detrusor muscle as submucosal channel before entering into the lumen of the bladder. Upon contraction of the detrusor muscle, ureter lumen collapses between the mucosa and the detrusor muscle, creating thereby a valve mechanism that 
prevents reflux of urine from the bladder to the ureter. Reflux occurs in cases where the channel between the submucosa and the detrusor muscle is short, or it is absent, or there is weak support from the detrusor muscle $(4,5,6)$. This situation is due to disturbed/ decreased proportion of the length of the ureters' submucosal tunnel to the diameter of the ureter, which is normally in the range from $4: 1$ to $5: 1$. The decrease in this ratio implies that the submucosal tunnel is short, the urethra has wider diameter and the ureters' insertion is lateralized to the normal trigone of the bladder. This means that the physiological valve mechanism that prevents reflux is incomplete. Usually its weight corresponds to the size of the degree of deformity of the uretero-vesical junction. The incidence of the occurrence of VUR in the pediatric population is $0.4-1.8 \%$ (7).

Depending on the factors that have caused, VUR can be primary and secondary. Primary VUR is a congenital anomaly of the insertion of the ureter into the bladder, the majority of cases are with primary VUR, which tends to spontaneous resolution after maturation of the uretero-vesical circuit, especially in male children older than 5 years. There is a strong genetic correlation with disease appearance in certain families. VUR can be isolated or can be associated with other abnormalities of the genitourinary tract (6).

Secondary VUR is a result of an organic or functional obstruction of the evacuation of the urine from the bladder. As a result, there is an abnormally high pressure in the bladder (e.g. rear valve ureter, neurogenic bladder, myelomeningocele, spine injuries, double ureter, ectopic ureter, sub vesical obstruction etc.) (4).

Diagnosis is made through heteroanamnestic data, clinical investigations and the following diagnostic methods: prenatal ultrasound diagnostics, voiding cystourethrogram (golden standard) - standard investigation which gives accurate anatomical detail and gradation of the reflux, direct radioisotope voiding cystography and echo tomography (The American Urological Association, 1997). Additional diagnostic methods that can help in evaluating the severity of VUR are CT, MRI, radioisotope methods (DMSA static scan and dynamic DTPA renal scan), urodinamic examinations (8).

Aim of the study was to evaluate the efficiency of two different surgical treatments of VUR on succesfull rate and patient outcome.

\section{METHODS}

\section{Patients}

Grading the severity of reflux in all patients was made according to the International Reflux Study Committees in 5 groups. The degree of the reflux is estimated after a voiding cystourethrogram is made. It defines the

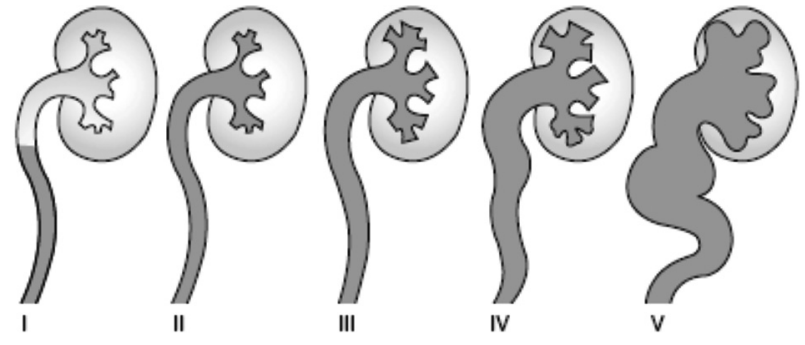

Figure 1. Displaying the urinary tract in the presence of VUR - I, II, III, IV, V degree

extent of the reflux, the appearance of the ureter, renal pelvis and calyces (Figure 1) $(5,9)$.

Gr. I: VUR limited to the ureter

Gr. IIa: VUR in the ureter and/ or pelvis

Gr. IIb: VUR to the calyces, but without their dilation

Gr. III: Moderately dilated ureter and pelvis, with blunting of the fornices

Gr. IV: Moderately dilated ureter and pelvis, with blunting of the fornices, but there is dilation of the entire collection system of the kidney

Gr. V: Pronounced dilatation and ureteral tortuosity, with enormous dilation of the pelvis and calyces and loss of renal parenchyma.

Generally accepted indications for surgical treatment were the following: high grade reflux, increasing of the existing lesions and/ or occurrence of new scars in renal parenchyma, recurrent pyelonephritis, urinary infections with febrile episodes while receiving antibiotic prophylaxis and finaly failure or lack of cooperation on the conservative treatment (3).

In the preoperative period biological samples were taken for laboratory tests, such as: urine culture, blood test, blood group determination, C-reactive protein in serum, degradation products (urea and creatinine), examination of urinary sediment (color, odor density, proteinuria, leukocituria, and bacteriuria). The obtained results, together with other medical history of the patients were crucial for forming a general picture of health condition of the patient and evaluation of anesthesiology risk of surgery.

\section{RESULTS}

At the Clinic of Pediatric Surgery in Skopje in the period from 1999 to 2014, 76 children (114 ureters) with symptomatic primary VUR diagnosed with prenatal ultrasound diagnostics, voiding cystourethrogram or direct radioisotope voiding cystography were surgically treated. The treatment was made with "STING" endoscopic procedure or an open surgical procedure. 44 patients (67 ureters) were treated with an open surgical technique. Of those, 30 were female (average age of 6 years) 
Table 1. Characteristics of the study group

\begin{tabular}{|c|c|c|c|c|}
\hline \multirow{2}{*}{ study group } & \multicolumn{2}{|c|}{ open surgical treatment } & \multicolumn{2}{|c|}{ endoscopic treatment } \\
\hline & male & female & male & female \\
\hline number of patients & 14 & 30 & 7 & 25 \\
\hline age (mean value) & 4.7 & 6 & 4.7 & 6 \\
\hline total number of ureters & \multicolumn{2}{|c|}{67} & \multicolumn{2}{|c|}{47} \\
\hline children with unilateral reflux & \multicolumn{2}{|c|}{33} & \multicolumn{2}{|c|}{17} \\
\hline children with bilateral reflux & \multicolumn{2}{|c|}{17} & \multicolumn{2}{|c|}{15} \\
\hline children with II grade of reflux & \multicolumn{2}{|c|}{0} & \multicolumn{2}{|c|}{3} \\
\hline children with III grade of reflux & \multicolumn{2}{|c|}{0} & \multicolumn{2}{|c|}{15} \\
\hline children with IV grade reflux & \multicolumn{2}{|c|}{13} & \multicolumn{2}{|c|}{10} \\
\hline children with V grade reflux & \multicolumn{2}{|c|}{31} & \multicolumn{2}{|c|}{4} \\
\hline hospitalization in days (average) & \multicolumn{2}{|c|}{9} & \multicolumn{2}{|c|}{1.5} \\
\hline
\end{tabular}

and 14 were male (average age of 4.7 years). Reflux was diagnosed on the right ureter in 20 patients, 13 children had reflux on the left ureter and 17 children had bilateral reflux. VUR grade IV was determined in 13 patients. The number of children with VUR grade V was 31 . All children were treated with intravesical and extavesical reinplantation of the reflux ureter into the bladder wall. Politano-Leadbetter access was used. The average time of hospitalization for these patients was 9 days (Table 1).

32 patients (47 ureters) were treated with endoscopic treatment with submucosal injection of copolymer dextranomer/ hyaluronic acid at the junction of reflux ureter with the bladder - "STING" procedure. 25 patients were female (average age of 6.1 years) and 7 were male (average age of 4.7 years). This study included only children which were applied to monitoring for the overall protocol. Reflux was diagnosed on the right ureter in 7 patients, 10 children had reflux on the left ureter and 15 children had bilateral reflux. Of these, three were grade II, 15 were grade III, 10 had grade IV and 3 children had grade V VUR. One patient with grade IV VUR of the left ureter was diagnosed with hypoplasia of the left kidney. The average time of hospitalization for these patients was 1.5 days.

\section{Open surgical technique}

Open surgical technique was used to increase the length of intravesical ureter. All patients were treated with intravesical reinplantation of the ureter into the bladder wall. Politano-Leadbetter access was used. The average time of the intervention was about 90 minutes in unilateral reflux and in bilateral, surgery lasted $120 \mathrm{~min}$ utes. During the operation, nearly all patients were given at least one unit of blood and/ or blood derivatives.

After the open surgical technique all patients received double antibiotic therapy. The need for analgesics lasted for 3 to 4 days. Hematuria was noted also in all children. Its duration was 3 to 5 days. The majority of children were given an additional unit of blood and/ or blood derivatives. Urinary catheter is extracted in the sixth postoperative day. Retrovesical drain is extracted the next day. Ureteric stent was extracted in average the eighth postoperative day. After removing the stents, control ultrasonography was performed. Complete blood count, by examining the renal function: degradation products (urea and creatinine), examination of urinary sediment was made every second day.

The final result in these patients meant a reduction of 3 degrees of the initial degree of VUR, mostly Grade $\mathrm{V}$ to grade II or I. Average time of hospitalization for these patients was 9 days (from 5 to 13 days).

One act surgery was used in 33 patients with VUR of the left or right ureter, and bilateral VUR was present in 17 patients. 12 cases were treated preliminary with uretero-cutaneo-stoma. In bilateral uretero-cutaneo-stomas, reimplantation was done in two consecutive acts, separately for each ureter.

Treatment in two acts was indicated because of the existence of extreme expansion of the diameter of the lumen of the ureter, severe hydronephrosis or poor general health of patients.

Desired result represented the achievement of proportion for the length of the submucosal tunnel of the ureter to the ureter - 4-5:1. With the open surgical tehnique 62 ureters showed lowering the rate of VUR by two or more grades. In 5 ureters the results were not satisfying, due to progressive rising of VUR grade after the surgery (3), VUR on the contralateral ureter (2).

\section{Endoscopic treatment}

32 patients (47 ureters) were treated with endoscopic treatment with submucosal injection of copoly- 
mer dextranomer/ hyaluronic acid in the mouth of the reflux ureter, - "STING" procedure.

In endoscopic treatment, there was no need for postoperative antibiotic therapy or analgesics. There was no need to ordinate blood and/ or blood derivatives. Antibiotic prophylaxis was given before treatment. Patients receiving anticholinergics continued with their therapy.

The final result in these patients meant a decrease of 2 degrees of the initial degree of VUR, usually from grade IV to grade II or I.

The evaluation of the results of the treatment was done mainly according to the following criteria: reduced grade of reflux, maintaining renal function, absence of urinary infection and postoperative complications (contralateral reflux, ureteral obstruction, additional disorders, and dysfunctional bladder).

After discharge from our department, all patients were monitored with ultrasonography review 7 days after surgery (to verify the presence of a bolus) and six weeks after the intervention (to determine the extent of possible hydronephrosis). Radio isotopic cystography was performed 6 months after surgery. In cases where the finding was inconclusive, voiding cystourethrogram was performed.

Out of all treated 76 children, 56 (80 ureters) conducted over the whole monitoring protocol. The reduction of 2 levels with VUR endoscopic procedure or 3 degrees in open surgical technique and absence of postoperative complications is accepted as a good result (3). In open surgical technique, 40 ureters $(93.8 \%)$ achieved a good result.

Endoscopy definitely solved the problem in 34 ureters or $70 \%$ of the patients. VUR has been detected again on the 13 operated ureters or more often on the contralateral ureter. They were successfully treated with re-endoscopy.

\section{DISCUSSION}

Treatment of children with reflux tends to prevent kidney infection, kidney damage and complications caused by kidney damage. Treatment includes pharmacotherapy, surgical treatmant and monitoring. Greenfield and Wlaker united several general principles for the treatment of children diagnosed with VUR (3). Spontaneous resolution of VUR in about $70 \%$ is common in children younger than 5 years and in lower grade reflux (gr. 1, gr. 2), grade 3 have spontaneous resolution of $50 \%$, and less likely in children over 5 years. It is unlikely that expressed reflux will spontaneously withdraw. Sterile reflux generally does not lead to reflux nephropathy, long-term antibiotic prophylaxis in children is safe and surgery that corrected VUR is highly successful $(10,11)$.
Drug therapy with antibiotic prophylaxis is considered successful if the child does not get an infection; do not develop kidney damage and scarring in the parenchyma and VUR spontaneously quit (4).

Anticholinergic and bladder training can ameliorate the symptoms of dysfunctional voiding and reduce the risk of infection.

Open surgery involves modification of dysfunctional uretero-vesical circuit, which creates a ratio of 4 : 1 to $5: 1$ in length for intramural ureter to the diameter of the ureter (6).

Endoscopic correction of VUR is injection of natural or synthetic substances in the posterior muscle wall of the uretero-vesical circuit. Subsequent swelling suppresses and elevates the urethral lumen so that it prevents reflux.

Depending on sex, age of the patient, grade of reflux, the changes in the renal parenchyma, systemic changes that can note in the presence of VUR will decide which type of treatment would be an appropriate choice for a particular patient. Each treatment is indicated in varying degrees of development of the disease (9).

Although statistics shows that open surgical technique is superior to "STING" procedure, however endoscopy proved better in terms of time of verticalization of the patients, the need to receive additional drug therapy, blood loss during operation and the duration of the operation (11). But we cannot favor any operational method because we believe that both methods have their indicational area in appropriate developmental stage of VUR (10).

\section{CONCLUSION}

Open surgical procedure is reserved for more complicated VUR cases (grade IV-V), and for patients with previously failed endoscopic procedure. This surgical method is superior in terms of satisfactory end results. This is relatively inexpensive method, but the time of verticalization of the patients, the need to receive additional drug therapy, long time of operation and anesthesia, grow up the cost.

Endoscopic treatment ("STING" procedure) can be applied in patients with VUR grade greater than 2, but with previously failed conservative treatment and other conditions. Deflux product is expensive, but the one-day surgery, short time of operation and anesthesia reduces the hospital costs. Patient assessment and decision on which method will be used should always be made individually for each child.

\section{Conflict of interest}

All authors agreed for this paper to be published, and report no conflict of interest. 


\title{
Sažetak
}

\section{EVALUACIJA DVE HIRURŠKE PROCEDURE U LEČENJU PRIMARNOG VEZIKOURETERALNOG REFLUKSA KOD DECE: PETNAESTOGODIŠNJE ISKUSTVO}

\author{
Memeti Shaban, ${ }^{1,2}$ Petrovski Mile, ${ }^{1}$ Petrovski Pero, ${ }^{1}$ Simeonov Risto, ${ }^{1}$ Kamilovski Marjan, \\ Todorovic Lazar, ${ }^{1}$ Ziberi Jetmir, ${ }^{1}$ Ristevski Toni, ${ }^{1}$ Lumani Njomza, ${ }^{1}$ Mihajlova Mila, ${ }^{1}$ Ristovska Gordana ${ }^{2}$ \\ ${ }^{1}$ University Clinic for Pediatric Surgery, Faculty of Medicine - Skopje, \\ "Ss. Cyril and Methodius" University - Skopje, Republic of Macedonia \\ 2 Institute of public health of Republic of Macedonia, Skopje, Republic of Macedonia
}

Cilj: Cilj studije je bio procena uspešnosti dva različita hirurška tretmana vezikoureteralnog refluksa (VUR), kroz stopu uspešnosti i ishod lečenja.

Metode: Retrospektivna studija o deci s primarnim VUR-om i njihovo hirurško lečenje od 1999. do 2014. godine, na Univerzitetskoj Klinici za dečiju hirurgiju u Skoplju. Ukupno 76 dece (114 uretera) s VUR-om, u rasponu od drugog do petog stepena, je lečeno hirurški. Od toga 44 pacijenta (67 uretera) je lečeno otvorenom hirurškom tehnikom, a 32 pacijenta (47 uretera) je endoskopski lečeno "Sting" procedurom. Analizirani su sledeći parametri: trajanje intervencije, trajanje hospitalizacije, potreba za korišćenjem antibiotika i analgetika u terapiji i potreba za transfuzijom krvi i krvnih derivata. Rezultat hirurškog lečenja je takođe praćen. Dobrim rezultatom se smatra smanjenje VUR-a za 2 stepena upotrebom endoskopske metode ili 3 stepena kod pacijenata lečenih otvorenom hirurškom tehnikom.

Rezultati: Pacijenti lečeni otvorenom hirurškom procedurom, bili su hospitalizovani u proseku 9 dana (raspon od 5 do 13 dana). Sva deca su dobila dvostruku

\section{REFERENCES}

1. Bailey RR, Lynn KL, Robson RA. End stage reflux nephropathy. Ren Fail. 1994; 16(1): 27-36.

2. Pirker ME, Colhoun E, Puri P. Renal scarring in familial vesicoureteral reflux: is prevention possible? J Urol. 2006; 176(4 Pt 2): 1842-6.

3. Lenaghan D, Whitaker JG, Jensen F, Stephens FD. The natural history of reflux and long term effects of reflux on the kidney. J Urol. 1976; 115(6): 728-30.

4. Baskin L, Kogan B.Handbook of Pediatric Urology. Lippincott Williams \& Wilkins Philadelphia, 2005.

5. Lebowitz RL, Olbing H, Parkkulainen KV, Semllie JM, Tamminen-Mobius TE. International system of radiographic grading of vesicoureteric reflux. International reflux study in children. Pediatr Radiol. 1985; 15(2): 105-9.

6. Khouri EA, Darius JB. Vesicoureteral reflux. In: Wein AJ, Kavoussi LR, Novick AC, Partin AW, Peters CA, eds. antibiotsku terapiju. Potreba za analgeticima trajala je od 3 do 4 dana. $90 \%$ tretirane dece imalo je potrebu za transfuzijom krvi i / ili krvnih derivata. Stopa uspeha ove metode je 93,8\%. Endoskopska procedura je izvedena po tipu jednodnevnog hirurškog zahvata. Prosečno trajanje je bilo 15 minuta. Jedna, profilaktička doza antibiotika je ordinirana. Nije bilo potrebe za transfuzijom krvi i / ili krvnih derivata. Ukupna uspešnost lečenja ovom metodom je oko $70 \%$.

Zaključak: Otvorena hirurška procedura se koristi za složenije slučajeve, VUR IV-V stepena ili ranije neuspešno lečenih. Endoskopska "Sting" procedura se najčešće koristi kod pacijenata s VUR stepenom većim od 2, nakon prethodno neuspešnog konzervativnog lečenja, infekcije mokraćnih puteva praćene febrilnošću uprkos antibiotskoj profilaksi i/ili kod pojave novih ožiljaka u bubrežnom parenhimu. Procena pacijenata i odluka o izboru metode lečenja uvek mora biti individualna za svako dete.

Ključne reči: deca, primarni vezikoureteralni refluks, hirurško lečenje, endoskopsko lečenje.

Campbell-Walsh Urology: Expert Consult Premium Edition. 10th ed. USA: Elsevier Saunders; 2011.p. 3267-310.

7. The American Urological Association Pediatric Vesicoureteral Reflux Guidelines Panel. Report on the management of the primary vesicoureteral reflux in children. American Urological Association. 1997 Available at http://www.auanet.org /common/pdf/education/Arc-Vesicoureteral-Reflux.pdf.

8. Greenfield SP, Wan J. Vesicoureteral reflux: practical aspects of evaluation and management. Pediatr Nephrol. 1996; 10(6): 789-94.

9. O’Donell B, Puri P: Endoscopic correction of primary vesicoureteral reflux: results in 94 ureters. BMJ (Clin Res Ed). 1986; 293(6559): 1404-6.

10. Stenberg A, Lackgren G. A new bioimplant for the endoscopic treatment of vesicoureteral reflux: experimental and short term clinical results. J Urol. 1995; 154(2): 800-3.

11. Sung J, Skoog S.Surgical management of vesicoureteral reflux in children. Pediatr Nephrol. 2012; 27(4): 551-61.

\section{Correspondence to / Autor za korespondenciju}

Ass. Dr Shaban Memeti

University Clinic for Pediatric Surgery, Faculty of Medicine - Skopje,

"Ss. Cyril and Methodius" University - Skopje

1000 Skopje, Republic of Macedonia

Tel: (+389-2) 31250 44; Fax: (+389-2) 32233 54; E-mail: shmemeti@iph.mk 